慶應義塾大学学術情報リポジトリ

Keio Associated Repository of Academic resouces

\begin{tabular}{|c|c|}
\hline Title & Characteristics of phospholipid transacylase of escherichia coli \\
\hline \multicolumn{2}{|l|}{ Sub Title } \\
\hline Author & $\begin{array}{l}\text { 本間, 浩(Honma, Hiroshi) } \\
\text { 工藤, 一郎(Kudo, Ichiro) } \\
\text { 并上，圭三(Inoue, Keizo) } \\
\text { 野島, 庄七(Nojima, Shoshichi) }\end{array}$ \\
\hline Publisher & 共立薬科大学 \\
\hline Publication year & 1987 \\
\hline Jtitle & $\begin{array}{l}\text { 共立薬科大学研究年報 (The annual report of the Kyoritsu College of } \\
\text { Pharmacy). No.32 (1987. ) , p.55- 55 }\end{array}$ \\
\hline \multicolumn{2}{|r|}{ 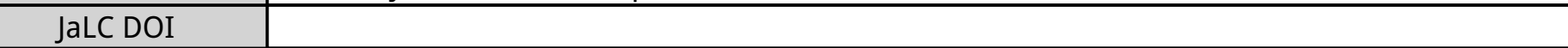 } \\
\hline \multicolumn{2}{|l|}{ Abstract } \\
\hline Notes & 抄録 \\
\hline Genre & Technical Report \\
\hline URL & $\begin{array}{l}\text { https://koara.lib.keio.ac.jp/xoonips/modules/xoonips/detail.php?koara_id=AN00062898-0000003 } \\
\text { 2-0055 }\end{array}$ \\
\hline
\end{tabular}

慶應義塾大学学術情報リポジトリ(KOARA)に掲載されているコンテンツの著作権は、それぞれの著作者、学会または出版社/発行者に帰属し、その権利は著作権法によって 保護されています。引用にあたっては、著作権法を遵守してご利用ください。

The copyrights of content available on the KeiO Associated Repository of Academic resources (KOARA) belong to the respective authors, academic societies, or publishers/issuers, and these rights are protected by the Japanese Copyright Act. When quoting the content, please follow the Japanese copyright act. 


\title{
Characteristics of Phospholipid Transacylase of Escherichia coli*
}

\author{
Hiroshi Homma, Ichiro Kudo, ${ }^{* *}$ Keizo Inoue** and Shoshichi Nojima*** \\ 本間 浩, 工藤一郎, 井上圭三, 野島庄七
}

Previously we have investigated the incorporation of radiolabeled free fatty acids into 2-acyl lysophospholipids by the envelope fraction of $E$. coli (HOMMA et al (1981) Biochim. Biophys. Acta). Their incorporation was found completely dependent on the presence of ATP. The incorporation was not observed from acyl Coenzyme A (acyl CoA), and was markedly stimulated by the addition of acyl carrier protein (ACP). Thus the acyltransferase of 2-acyl lysophospholipid was presumed to utilize acyl ACP preferentially over acyl CoA. ATP was appreciably required for the activation of fatty acids to acyl ACP. In the course of this investigation, it was observed that radiolabeled 2-acyl lysophospholipid was still acylated to diacylphospholipid even in the absence of ATP. This result suggested that there exist some acyl donor (s) in the envelope fraction except for free fatty acids and acyl CoA. In a previous paper, we have demonstrated that the diacylphospholipids in the envelope fraction were the acyl donor ( $s$ ) and that acyl groups were provided from the diacylphospholipids directly to the lysophospholipid (HOMMA et al (1982) J. Biochem. 91 1093-1101). This was then the first demonstration of a new type of the activity of phospholipid transacylase in $E$. coli. In this communication we studied the characteristics and specificities of this phospholipid transacylase of $E$. coli.

The activity catalyzed a reversible transfer of an acyl group between diacylphospholipids. Acyl group in the 1-position of glycerol backbone was selectively transferred and palmitic acid was the only fatty acid species transferred. Presumably neutral lipids do not serve as substrates.

The transacylase was firmly associated with the envelope fraction of $E$. coli. Potasium chloride or urea was not effective in solubilization of the activity and about half of the activity was only solubilized with Triton $\mathrm{X}-100$. This observation was consistent with the equal distribution of the activity between the outer membrane and the inner membrane of $E$. coli. Functional aspect of this phospholipid transacylase of $E$. coli was also discussed.

＊＼cjkstart本報告は $J$. Biochem., 101, 1033-1039（1987）に発表.

** 東京大学薬学部

*** 帝京大学薬学部 